\title{
H2AZ1 wt Allele
}

National Cancer Institute

\section{Source}

National Cancer Institute. H2AZ1 wt Allele. NCI Thesaurus. Code C126765.

Human H2AZ1 wild-type allele is located in the vicinity of $4 \mathrm{q} 24$ and is approximately $2 \mathrm{~kb}$ in length. This allele, which encodes histone H2A.Z protein, plays a role in chromatin packaging. 